\title{
The Effect of the 5E Learning Model Supported with Material Ensuring Conceptual Change on Science Achievement: The Example of "Heat and Temperature"
}

\author{
Yılmaz Vahit Işcan' \& Hatice Güngör Seyhan ${ }^{\varpi_{2}}$ \\ 1 Yakupoğlan Middleschool, Sivas, Turkey \\ 2 Department of Chemistry Education, Sivas Cumhuriyet University, Sivas, Turkey \\ $\bowtie$ hgungor@cumhuriyet.edu.tr
}

\begin{abstract}
This study seeks to examine the effect of the $5 E$ learning model, as one of the constructivist learning approach models, supported by conceptual change texts and enriched with relevant guidance materials on eliminating the fifth-grade students' $(n=42)$ misconceptions about "Heat and Temperature". A quantitative research approach was employed by conducting the pre-test and post-test quasi-experimental design of the non-equivalent groups, namely the experimental and control groups. Before the implications, the Heat and Temperature Achievement Test (HTAT) was used to determine the academic achievement levels of the students in the experimental and control groups in the topic of heat and temperature. The pre-test results between both group students did not find a significant difference. There was a significant difference in favor of the experimental group between the HTAT post-test results. From the results obtained within the scope of the study, it was concluded that this learning model was effective in eliminating the fifth-grade students' misconceptions about the topic of heat and temperature.
\end{abstract}

Keywords: conceptual change texts, heat and temperature, misconception, 5E learning model, pre-service science teachers

How to Cite: Iscan, Y., \& Seyhan, H. (2021). The Effect of the 5E Learning Model Supported with Material Ensuring Conceptual Change on Science Achievement: The Example of "Heat and Temperature". Mimbar Sekolah Dasar, 8(3), 250-280. doi:https://doi.org/10.53400/mimbar-sd.v8i3.33044.

INTRODUCTION In parallel with the developments in science and technology, the existing accumulation of knowledge is increasing day by day (Köse, Ayas \& Uşak 2006). This increase in knowledge brought along contradictions about what the content of the curriculum would be. In other words, concept teaching has come to the fore, especially after the 1980s (Ayas \& Özmen, 2002; Saka, 2006). This situation has revealed new research areas such as concept, concept teaching, misconceptions, and elimination of misconceptions.

Concepts are not formed amid the individual only through the information provided by teachers in the learning environment. However, they can also be formed depending on the students' interpretation of the events happening in their environment and their interaction with other individuals. These kinds of experiences of students can also cause them to misconfigure concepts (Hewson \& Hewson, 1984; Palmer, 2001; Treagust, 1988). When many studies on concept teaching are examined, it is observed that a definition is made for non-scientific concepts and views in students: intuitive thoughts (Osborne, 1985), misconception (Clement, 
Yılmaz Vahit Işcan \& Hatice Güngör Seyhan, The Effect of the 5E Learning Model Supported...

Brown \& Zietsman, 1989; Helm, 1980), alternative structures (Driver, 1981), preliminary concepts (Novak, 1977), children's science (Gilbert, Osborne \& Fensham, 1982; Gunstone, 1990; Treagust, 1988). Based on all these definitions, it was revealed that these non-scientific views of the students, namely learning to prevent their learning of new concepts, are able to cause them to misinterpret the events they encounter in daily life, and cause learning problems such as the failure to reach an acceptable solution when faced with any problem situation (Akgün \& Deryakulu, 2007). In order to increase the success in concept teaching, it is not enough only to identify these misconceptions in students (Çallk et al., 2008). Therefore, the studies to eliminate these misconceptions are also of great importance in science education. Strategies used to ensure a conceptual change in concept teaching in order to eliminate misconceptions have been a guide for science educators in particular (Driver \& Oldham, 1986; Posner, Strike \& Hewson, 1982).

\section{Misconceptions and Conceptual Change}

Constructivism forms the basis of research in the field of misconceptions. John Dewey, Jerome Bruner, and Jean Piaget contributed to the development of this view in which they expressed it in terms of "constructivism" and "structuralism", which attaches great importance to students' alternative concepts. The main foundations of misconceptions are based on David Ausubel's (1968) "Theory of Meaningful Learning", George Kelly's (1955) "Personal Construct Theory" and Lev Vygotsky's (1962) "Socio-cultural Theory". The main reasons for students' misconceptions can be very diverse:

- The use of language different from the scientific meaning in daily life,

- In the educational process at school, the student constructs the concept incorrectly.

- Giving wrong information to the student formal and informal learning environments,

- Textbooks used by the student formal and informal learning environments.

- The language that the teacher uses in the classroom, which is not clear or understandable.

- Incorrect memorization of scientific knowledge by students and interpretation,

- Teaching methods applied in lessons may also cause misconceptions in students (Anderson, 1990; Storey, 1991; Sander, 1993; Mestre, 1994).

In recent years, studies aimed at eliminating misconceptions rather than identifying students' misconceptions in science education have gained intensified (Aykutlu \& Şen, 201 1; Erdoğan \& Özsevgeç, 2012; Ürek \& Tarhan, 2005). Techniques used to detect and eliminate misconceptions in this and similar studies; interview, TGA, concept maps, open-ended questions, and multiple-choice tests are used (Hewson \& Hewson, 1984). At this point, it is extremely important for the teacher to choose the methods and techniques used well, to use them correctly and, above all, and to keep them student-centered, in eliminating misconceptions and confusion (Kaplan \& Arslan, 2002). It has become a necessity to develop 
materials that provide a conceptual change in effective concept teaching, in which persistence comes to the fore and memorization is avoided (Okur, 2009). As a result of the literature reviews on the conceptual change model, Okur (2009) found that many studies examined the effectiveness of materials and/or strategies by using them alone. The results revealed that students became bored due to the frequent use of worksheets, and situations such as getting away from the teaching environment became widespread (Türk \& Çalık, 2008). In addition, as a result of the investigations, it is expressed that although it is accepted to be useful in conceptual change texts, some findings reveal that no curriculum or book covers all alternative concepts, which can cause problems in reading (Dole, 2000). Moreover, excessive use of analogies is considered having a disadvantage (Rogers Growing individuals who have an active role in acquiring knowledge, can conduct research to gain in-depth knowledge, and use the information learned constitutes the basis of an educational approach transformed from behavioral theory to constructivism, 2000). On top of that, computer-aided educations are still not widespread, and there are some opposing views in addition to positive student attitudes (Saka \& Yılmaz, 2005; Uşun, 2006; Okur, 2009). In contrast to all the negatives emphasized, planning for an educational environment based on a constructivist learning approach, which combines worksheets, conceptual change texts, analogies, and computeraided materials, is considered to be effective. In this study, many strategies, methods and techniques were used together based on the $5 E$ learning model of the constructivist learning approach.

In the conceptual change model, which is defined as the reconstruction of the concepts that students have before teaching in order to learn scientific concepts and principles (Duit \& Treagust, 1998; Posner, Strike \& Hewson, 1982; White \& Gunstone, 1989), learning takes place with the change of existing knowledge schemes during the imbalance experienced by the individual when they encounter new information different from the information in the current scheme (Driver et al., 1994). Studies in which various activities based on conceptual change strategy are organized in order to provide conceptual change in concretizing abstract concepts have been examined. Some studies expressed that methods and techniques such as analogy (Bilgin \& Geban, 2001), conceptual change texts based on conceptual change strategy (Çaycı, 2007; Toka \& Aşkar, 2002), refuting texts (Palmer, 2003), worksheets (Atasoy, 2008; Özmen \& Yıldırım, 2005), computer-aided education (Coştu, Çepni \& Yeşilyurt, 2002; Saka \& YIImaz, 2005), and concept maps (Çıldır \& Şen, 2006) can be more effective when used together (Jaakkola \& Nurmi, 2008; Kurnaz \& Çalık, 2008; Okur, 2009; Taşlıdere, 2013; Türk \& Çalık, 2008). Growing individuals who have an active role in acquiring knowledge, can conduct research to gain in-depth knowledge, and use the information learned constitutes the basis of an educational approach transformed from behavioral theory to constructivism (Board of Education, 2013). Learning in constructivism is considered as the exchange of alternative 
Yılmaz Vahit Işcan \& Hatice Güngör Seyhan, The Effect of the 5E Learning Model Supported...

concepts that the student has with scientific concepts (Driver, 1981). The point to be considered in the conceptual change model is how the strategies or activities to be carried out according to this model will take place in the classroom. It is known that using only one conceptual change strategy is not enough to keep students' interest in the lesson awake (Rogers, Huddle, \& White, 2000; Türk \& Çalık, 2008). With this study to be carried out, rich learning environments will be presented to the students and it will contribute to the elimination of misconceptions of the students. This study used conceptual change texts, analogies, experimental applications and computer-assisted learning methods to eliminate the misconceptions of students.

\section{E Learning Model}

Although constructivist learning is not an instructional theory but a learning theory (Richardson, 1997), it emphasizes a different classroom instruction from the behavioral approach to realize conceptual and meaningful learning. The constructivist learning approach argues that an individual actively constructs his or her knowledge in accordance with the concepts in their existing cognitive structures. In addition, research on students' misconceptions has shown that it is necessary to develop instructional strategies suitable for constructivist learning (Lanier \& Little, 1986). The constructivist teachers use students' alternative concepts, thoughts, and ideas as the starting point of the lesson. In the classroom, they play a different role to guide, diagnose, motivate and create. For the student, a conceptual change requires a difficult mental effort because of the need to reorganize the relationship between existing concepts (Stofflett, 1994).

In 1967, Karplus proposed a theory that was influenced by Piaget's theory. According to this theory, science learning should be such that it enables students to self-organize new reasoning models. Karplus also stated the usability of a three-phase learning cycle based on this theory. In the second phase of the learning cycle, which in the first place is "exploration", concepts are presented and explained with the help of the active role of the teacher because Karplus (1977) argued that learning is obtained through explanation. The last phase is the "application" phase in which the concepts previously explained are then extended to new situations and applicable areas (Köseoğlu \& Kavak, 2001). This cycle was updated with the addition of an "introduction and evaluation" phase in accordance with the research that has been carried out from time to time, and the three-phase cycle was changed to five phases (Hanuscin \& Lee, 2007). The stages of this cycle, called the $5 E$ learning model, are explained below (Seyhan \& Morgil, 2007): Engage: The activities in this section are carried out to arouse students' curiosity and attract their attention, encourage them to think and help reveal their prior knowledge, Exploration: At this stage, students make predictions, research, design and plan relevant resources and materials, collect data, create models they seek, reflect and evaluate possibilities on their own, Explanation: At this stage, students are starting to analyze what they 
have discovered. Their understandings become clear and change through reflective activities, Extension: At this stage, students have the opportunity to expand their understanding of concepts, facts, and events in the relevant topic and/or apply it to a real-world situation and Evaluation: This stage should be done throughout the learning experience. At this stage, the teacher should observe the students' knowledge and/or skills, the application of new concepts, and the change in their thoughts.

When the literature is examined for the most frequent topics encountered by students with the most alternative concepts, it is striking that one of them is "heat and temperature". Misconceptions about heat and temperature are presented not only in students but also in adults. These two concepts are used interchangeably as if the same concept is mentioned, especially in daily life. Most of the misconceptions about heat and temperature are objectbased concepts (Erickson 1979; Harrison, Grayson \& Treagust, 1999). Students perceive heat objectively, such as air or steam (Erickson 1979, Jara-Guerrero 1993). It is seen that the basis of misconceptions about heat and temperature are the interchangeable use of these two concepts (Jara-Guerrero 1993; Thomaz, Malaquias, Valenta \& Antunes, 1995). When the literature on heat and temperature topic is examined, it is noteworthy that students have difficulty in perceiving the fact that objects that stay in the same environment for a long time have the same temperature, they think that their sense of touch is sufficient in temperature detection, and they feel the objects at different temperatures when they touch them (Sari Ay \& Aydoğdu, 2015).

As a result of a study examining the effect of conceptual change texts on eliminating the misconceptions determined in the states of matter and the "heat" unit, it was found that the teaching based on conceptual change is more effective than traditional teaching in eliminating the misconceptions about heat and temperature (Sarl Ay, 2011). As a result of another study in which misconceptions were evaluated with three-step questions, it was observed that as the number of stages in concept tests increased, students' conceptual knowledge levels increased (Taşlıdere, Korur \& Eryılmaz, 2012). The result of the study examining the effect of laboratory implications based on the Predict-Observe-Explain method on preservice science teachers' understanding of heat and temperature found a significant positive effect of the implications on pre-service teachers' understanding of the concepts of heat and temperature compared to the laboratory technique based on the proof method (Durmuş, 2014). As a result of a study conducted on the effect of the $5 \mathrm{E}$ learning method in determining and eliminating the misconceptions of fifth-grade students about heat and temperature, it was found that meaningful learning occurred in the students in the experimental group (Sarkaya, 2019). 
Yılmaz Vahit Işcan \& Hatice Güngör Seyhan, The Effect of the 5E Learning Model Supported...

\section{Purpose and Importance of the Research}

One of the most important problems encountered in science teaching is misconceptions (Eryllmaz, 2002). Education and training have a crucial role in determining the causes of the formation of misconceptions, such as not being able to adequately understand and detect the existing misconceptions of students in concept teaching and starting the lesson without determining the readiness of the students for new concepts. In the Turkish Education system, the spiral learning approach is used to plan the curriculum of all disciplines (Demirel, 1999). This approach is often used in the constructivist learning approach and is student-centered. Its most important representative is Bruner. This approach coincides with Bruner's statement, "previous learning becomes the basis for subsequent learning, and the repetition of concepts is important when appropriate" (Sabu, 2008). Therefore, identifying existing misconceptions in students in science lessons will also facilitate the planned teaching of new information for future study of related concepts, phenomena, and events. All resources prepared without considering students' prior knowledge bring along the need for alternative resources (Okur, 2009). In this study, teaching was carried out in accordance with the $5 E$ learning model, which is one of the implications models of the constructivist learning theory. Different models such as learning circle, 7E, 4E are used in the constructivist learning theory in the classroom environment (Osborne \& Wittrock, 1983; Yager, 1991). This study initially aimed at determining the existing misconceptions of students about the topic of heat and temperature. Afterward, it aims at developing guidance materials equipped with strategies, methods, and/or techniques used to eliminate misconceptions as an alternative to the written sources used for the relevant course in the education system. It is thought that developing materials that provide conceptual change to eliminate these misconceptions and delivering them to the teachers of the relevant course are extremely important in terms of providing students' conceptual understanding. The main purpose of this study is to examine the effectiveness of the $5 E$ learning model enriched with conceptual change texts and guidance materials developed by the researchers on the topic of "Heat and Temperature" belonging to the "Matter and Change" unit of fifth-grade students. Based on this main purpose, the answers are presented in the following sub-problems:

1. Are there any misconceptions about the topic of "Heat and Temperature" in the experimental group, related to the application of the 5E learning model supported by conceptual change texts and relevant guidance materials, and the control group, related to the application of the 5E learning model envisaged by the Ministry of National Education (MoNE) Science curriculum?

2. To what extent can the students' misconceptions about the topic of "Heat and Temperature" be eliminated in the experimental group for which the 5E learning model supported by conceptual change texts and relevant guidance materials is applied? 
3. Is there a statistically significant difference in test results from the experimental group, related to the application of the 5 E learning model supported by conceptual change texts and relevant guidance materials, and the control group, regarding the implementation of the $5 E$ learning model envisaged by the Ministry of National Education (MoNE) science curriculum?

\section{METHOD}

\section{Research Model}

In this study, based on the cognitive gains on the topic of "Heat and Temperature" in the "Matter and Change" unit in the fifth-grade Science curriculum, a quasi-experimental design model with a pre-test - post-test control group was used to reveal the misconceptions of students.

\section{Study Group}

The target population consists of all fifth-grade students in Sivas City and Districts. The study group consists of 42 fifth-grade students from two different classes studying at a state secondary school in Sivas City in the fall semester of the 2019-2020 academic year. The implications were started by categorizing groups of students into the experimental group and the control group. The experimental group was assigned to apply the 5E learning model supported by conceptual change texts and enriched with relevant guidance materials, while the control group was assigned to apply the 5E learning model, including all the learningteaching activities envisaged by the Ministry of National Education for the Science course curriculum . All implication carried out with the students of both groups lasted for three weeks.

\section{Data Collection Tools}

\section{Heat and Temperature Achievement Test (HTAT)}

In this study, the Heat and Temperature Achievement Test (HTAT) was used. During the preparation phase of HTAT, a comprehensive literature review has been made on the topic of heat and temperature. After the literature review, the test was conducted by using the HTAT developed by Gürbüz (2008) to determine the misconceptions of primary school students. The original version of the achievement test consists of 20 questions with three stages. The Cronbach-Alpha reliability coefficient of the original test was found to be 0.72 . The content of the original test is suitable for the cognitive outcomes of sixth-grade students. Since the original test took place before the curriculum and system change in 2012, the need to rearrange the test was considered. According to the fifth-grade science curriculum determined by the Turkish Education system, the unit of Matter and Change aims at teaching topics such as "state change in matter, the distinctive properties of substances, heat and temperature and the effect of heat on substances". In the curriculum, it is expected that the learning has reached 
Yılmaz Vahit Işcan \& Hatice Güngör Seyhan, The Effect of the 5E Learning Model Supported...

cognitive results for the topic of heat and temperature in the third sub-unit. This was discussed within the scope of the study. Relevant cognitive outcomes include explaining the fundamental difference between heat and temperature and interpreting the results by conducting experiments on heat exchange as a result of mixing liquids with different temperatures..

The test items in the HTAT, which originally consisted of 20 multiple-choice questions, were examined by the researchers, and 15 items were selected and validity-reliability analyzes were started as it is. First of all, a specification table was created to test whether the questions in the first stage of the HTAT used in the study fully cover the targeted cognitive outcomes for the relevant chemistry topic. This specification table also constitutes evidence for content validity (Can Şen \& Eryllmaz, 2011). Furthermore, the specification table and HTAT test items were examined by the expert group. It can be foreseen that the expert group will consist of at least five people (Yurdugül, 2005). The expert group in this study consisted of five people, namely three science educators and two science teachers from faculty of education. The experts evaluated whether the questions covered all the outcomes and whether the questions were compatible with the relevant outcomes. The Lawshe (1975) technique was used to examine the consistency of the experts' opinions in which they evaluated the test items according to both criteria (Webb, 1997). This technique aims at determining whether test items are adequate, need to be regulated, and/or insufficient in measuring these outcomes. The findings that were obtained for the content validity ratios (CVR) calculated according to the relevant technique were evaluated by taking the value of .99 at the .05 significance level, considering that the number of experts was five (Veneziano \& Hoper, 1997). The content validity rate based on the opinions of five experts was considered statistically significant since it was above the specified criterion of .99. Accordingly, it was concluded that the multiple-choice questions in HTAT used in the study included both cognitive outcomes. In data analysis, questions with a content validity ratio of $\leq .99$ at the .05 significance level should be rearranged or removed from the test. Test items that were below this value were removed and/or some items were rearranged in line with expert opinions, and the test consisting of 10 multiple-choice items was given its final form. It concluded that the test items were statistically significant at the .05 level. Since the calculated CVR was $\geq .99$, the results were that the questions were removed, and/or rearranged and added. For the reliability analysis of HTAT, the test was administered to 200 different secondary school students before the main implications. After the statistical analyzes, the Cronbach-Alpha reliability coefficient of the finalized HTAT was calculated, and the a reliability coefficient of the test was found to be 0.79 . Therefore, the developed test is reliable.

Relevant literature on the analysis of answers to test items, such as two-stage tests, was reviewed, and the rubric used in Okur's (2009) study was taken as a basis. The data obtained 
from the achievement test, relating to the concept of heat and temperature, was then applied to all groups. The pre-test scores were determined based on the criteria presented in Table 1.

Table 1. Categories in Student Answers for HTAT

\begin{tabular}{llllll}
\hline Categories & Explanation & Score & Categories & Explanation & Score \\
\hline CA-CG & $\begin{array}{l}\text { Correct Answer- } \\
\text { Correct Grounds }\end{array}$ & $8 \mathrm{P}$ & NA-WG & $\begin{array}{l}\text { No Answer-Wrong } \\
\text { Grounds }\end{array}$ & 3 P \\
\hline NA-CG & $\begin{array}{l}\text { No Answer- Correct } \\
\text { Grounds }\end{array}$ & $7 \mathrm{P}$ & WA-WG & $\begin{array}{l}\text { Wrong Answer- } \\
\text { Wrong Grounds }\end{array}$ & 2 P \\
\hline WA-CG & $\begin{array}{l}\text { Wrong Answer- } \\
\text { Correct Grounds }\end{array}$ & $6 \mathrm{P}$ & WA-NG & $\begin{array}{l}\text { Wrong Answer-No } \\
\text { Grounds }\end{array}$ & $1 \mathrm{P}$ \\
\hline CA-WG & $\begin{array}{l}\text { Correct Answer- } \\
\text { Wrong Grounds }\end{array}$ & $5 \mathrm{P}$ & NA-NG & $\begin{array}{l}\text { No Answer-No } \\
\text { Grounds }\end{array}$ & 0 P \\
\hline CA-NG & $\begin{array}{l}\text { Correct Answer-No } \\
\text { Grounds }\end{array}$ & $4 \mathrm{P}$ & & & \\
\hline
\end{tabular}

\section{Implication Process}

A teacher and student material was prepared for both groups of students included in the study. The difference between the guidance materials for the students of the two groups lies in the strategies, methods, and techniques used. The guidance materials for the experimental group of students and the mentor teacher contains strategies, methods and techniques in accordance with the $5 \mathrm{E}$ learning model enriched with conceptual change texts and relevant guidance materials. Meanwhile, the guidance materials for the control group of students and the mentor teacher include all activities and strategies of the curriculum (5E learning model) implemented and envisaged by the Ministry of Education for the Science course. The implications of both groups of students were limited with the same mentor and the times determined by the Ministry of National Education (MoNE) and were carried out at the same time.

\section{RESULTS}

The fact that the number of experimental and control groups of students forming the study group in the study was less than 30 (21 students in the experimental group and 21 students in the control group) highlighted the use of non-parametric tests in the analysis of the data obtained within the scope of the study. However, by ignoring the low number of study groups, the results obtained from the tests on the assumption of normality with all the data obtained in the study showed the usability of parametric tests. In data analysis, various tests were used to determine the normality of the data distributions. The best known of these tests are Chi-Square, Kolmogorov-Smirnov, Lilliefors, and Shapiro-Wilk normality tests (Howitt \& Cramer, 2011; Tabachnick, Fidell \& Ullman, 2007; McKillup, 2011; Wilcox, 2011). The Shapiro-Wilk-W test is the most effective test for the normality assumption (Kul, 2014). 
Yılmaz Vahit Işcan \& Hatice Güngör Seyhan, The Effect of the 5E Learning Model Supported...

After determining the normal distribution of HTAT pre and post test data obtained from our study, a t-test was performed for independent groups, one of the parametric tests, in order to determine whether there is a significant difference between the data obtained from the HTAT pre-test applied before both implications of the experimental and control group students and $\left(t_{(42)}=0.728 ; p>0.05\right)$ values were reached as a result of the t-test. According to HTAT pre-test data analysis, a significant relationship was not observed between the pre-tests of the students of both groups. The results showed that the students of both groups performed the implications with a similar level of prior knowledge about heat and temperature. The T-test was conducted for dependent groups regarding the pre-test and post-test scores obtained from HTAT of the students in the experimental and control groups included in the study, and the results are presented in Table 2.

Table 2. T-Test Results for Dependent Groups Related to HTAT Pre- and Post-Test Scores of Experimental Group Students

\begin{tabular}{|c|c|c|c|c|c|c|c|}
\hline & & Average & $\mathbf{N}$ & $\begin{array}{c}\text { Std. } \\
\text { Deviation }\end{array}$ & $t$ & df & $\begin{array}{r}\begin{array}{r}\text { Significance } \\
\text { Level }\end{array} \\
\end{array}$ \\
\hline \multirow{2}{*}{$\begin{array}{l}\text { Exp. } \\
\text { Group }\end{array}$} & Pre-test & 23.00 & 21 & 3.47851 & \multirow{2}{*}{-7.740} & \multirow{2}{*}{20} & \multirow{2}{*}{0.000} \\
\hline & Post- test & 33.33 & 21 & 6.23164 & & & \\
\hline \multirow{2}{*}{$\begin{array}{l}\text { Control } \\
\text { Group }\end{array}$} & Pre-test & 21.14 & 21 & 4.95263 & \multirow{2}{*}{-4.236} & \multirow{2}{*}{20} & \multirow{2}{*}{0.043} \\
\hline & Post- test & 23.28 & 21 & 6.41984 & & & \\
\hline
\end{tabular}

Table 2 shows that the results found a significant relationship between the success scores in the HTAT pre-test and post-test of the students in the experimental and control groups $(p<0.05)$.

To determine whether there is a statistically significant difference between the conceptual understanding of the topic of heat and temperature between the experimental group students taught with the 5E learning model enriched with conceptual change texts and relevant guidance materials and the control group students taught in accordance with the $5 \mathrm{E}$ learning model envisaged by the Ministry of National Education (MONE) Science course curriculum, HTAT was applied to both groups of students after the implications as a post-test. The findings of the t-test for the independent groups performed are presented in Table 3.

Table 3. T-Test Results for Independent Groups of HTAT Post-Test Scores of Experimental and Control Group Students

\begin{tabular}{llrrrr}
\hline & Group & N & Average & Std. Deviation \\
\hline \multirow{2}{*}{ Post-test } & Exp. & 21 & 33.3333 & 6.23164 \\
\cline { 2 - 6 } & Control & 21 & 23.2857 & 6.41984 \\
\hline \hline \multirow{2}{*}{ Post-test } & & Levene test & t-test results \\
\cline { 2 - 6 } & & $\mathbf{F}$ & $\mathbf{t}$ & $\mathbf{d f}$ & ${ }^{*} \mathbf{p}$ \\
\hline
\end{tabular}


Table 3 shows the result of the t-test analysis for independent groups made according to the HTAT post-test data of the students in the experimental and control groups. It found a significant difference between the means of the groups in favor of the experimental group $(p<0.05)$. In other words, the teaching with the 5E learning model enriched with conceptual change texts and relevant guidance materials improved their conceptual understanding of heat and temperature more than the teaching used in the control group of students.

The responses of the students evaluated according to the categories in Table 1 were concluded in frequency and percentage. The results are presented below in a graphic for each question in HTAT one by one:



Figure 1. Analysis of Student Answers for Question-1 (f/\%)

- For the first question of HTAT, namely "Which of the following statements about the temperature of two iron tables, one big and the other small, stayed long enough in the same room is correct?", $4.8 \%$ of student responses were determined in the pre-test for the experimental group of students in the CA-CG category. This rate increased to $38 \%$ after the implications.



Figure 2. Analysis of Student Answers for Question-2 (f/\%)

- Based on the results for the second question in the "understand" level, namely "Which of the following do you think best expresses the temperature?", in the experimental group of students, 
Yılmaz Vahit Işcan \& Hatice Güngör Seyhan, The Effect of the 5E Learning Model Supported...

there was no feedback observed on the pre-test in the CA-CG category. Meanwhile, one student provided feedback with $4.8 \%$ in the post-test.

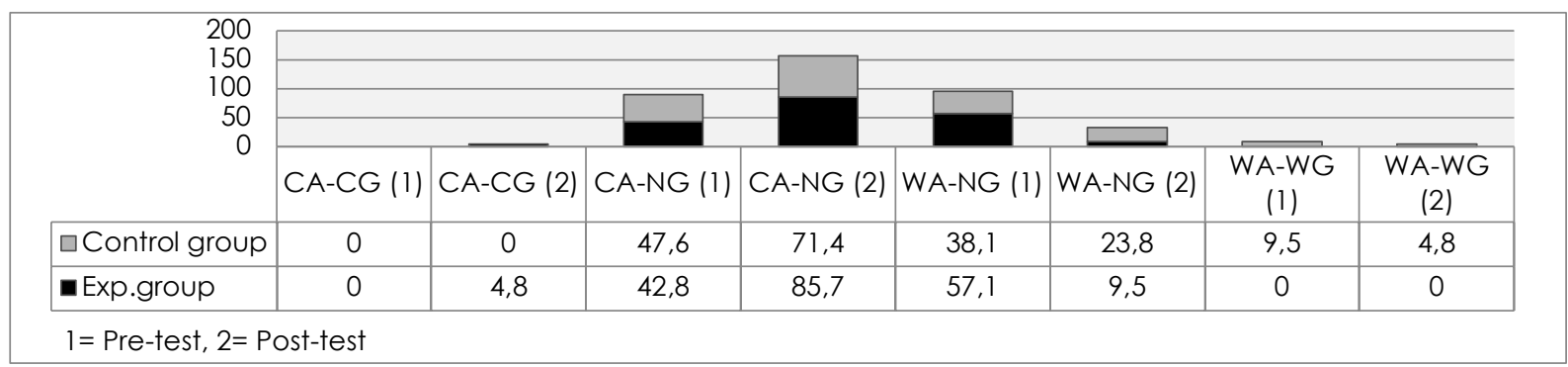

Figure 3. Analysis of Student Answers for Question-3 (f/\%)

- The third question of HTAT, namely "Which of the following do you think expresses the concepts of heat and temperature in the best way?" took place in the "remember" step of the taxonomy. In the student responses to this question, none of the experimental group students answered in the CA-CG category in the pre-test. In the post test, this rate increased to $4.8 \%$.

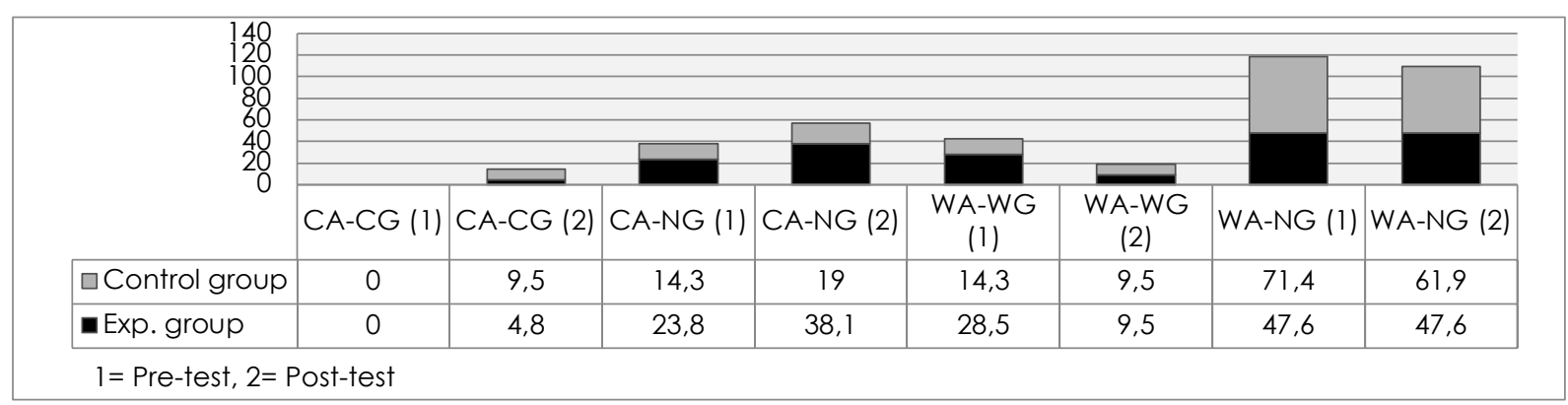

Figure 4. Analysis of Student Answers for Question-4 (f/\%)

- In the fourth question of the test at the "apply" level, namely " $200 \mathrm{ml}$ of water is placed in one of two beakers of the same size, and $100 \mathrm{ml}$ in the other and the water is heated for three minutes with two identical energy sources. Which of the following statements about the end temperatures of these waters with the same starting temperatures is correct?", none of the experimental group students answered in the CA-CG category in the pre-test.

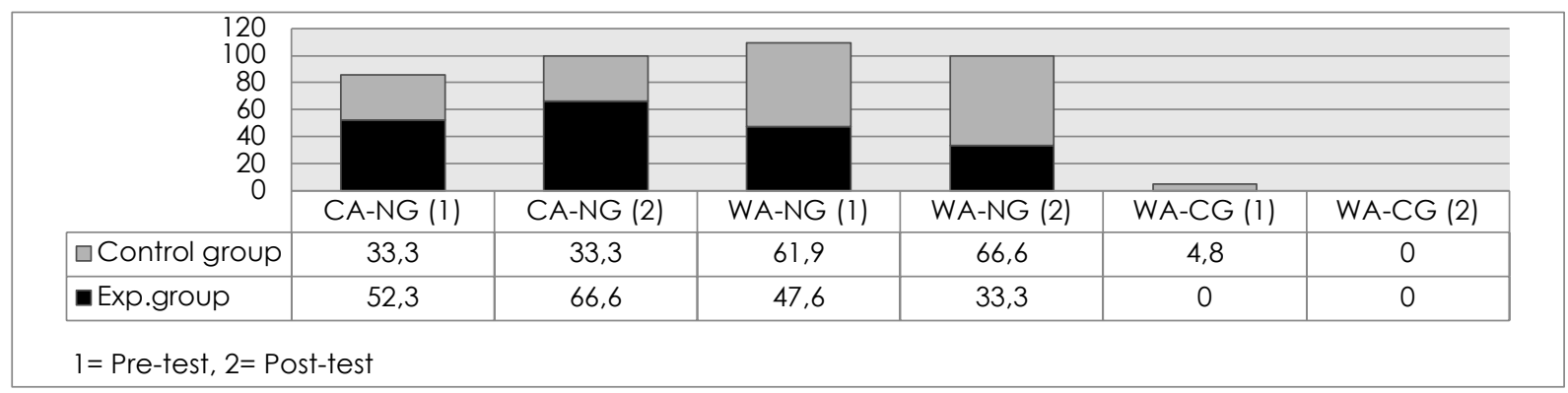

Figure 5. Analysis of Student Answers for Question-5 (f/\%)

- In the fifth question of the test at the "apply" level, namely "Which of the following statements about the final temperature of the mixture is correct when the water in two glasses at different temperatures is poured into a jug?", neither the experimental group of students nor the control 
group of students answered to this question in both the pre- and post-tests in the CA-CG category.



Figure 6. Analysis of Student Answers for Question-6 (f/\%)

- In the sixth question of the test, namely "It is measured that two objects at different temperatures that are in contact with each other have the same temperature after a while. Which of the following expresses this situation best?", none of the students in the experimental group responded in the CA-CG category in the pre-test, while $9.5 \%$ of them answered in this category in the post-test. The students in the control group did not answer in this category neither in the pre-test nor in the post-test.

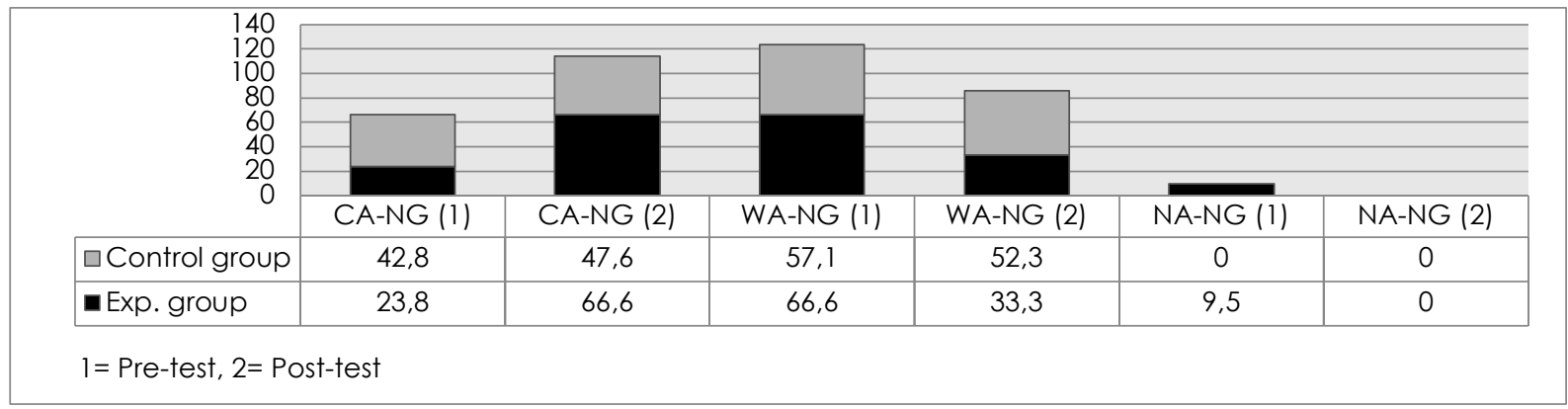

Figure 7. Analysis of Student Answers for Question-7

- The seventh question of the test was about heat and temperature units. In Figure 7, there was no students in any group responded in the CA-CG category.



Figure 8. Analysis of Student Answers for Question-8 (f/\%) 
Yılmaz Vahit Işcan \& Hatice Güngör Seyhan, The Effect of the 5E Learning Model Supported...

- In the eighth question of the test at the "create" level, namely "Which of the following statements is correct for half liter and one liter water heated in equal time periods in identical heaters?", none of the students from the experimental and control groups responded the question in the CA-CG category. However, in the post-tests, $9.5 \%$ of the experimental group students responded in the CA-CG category.

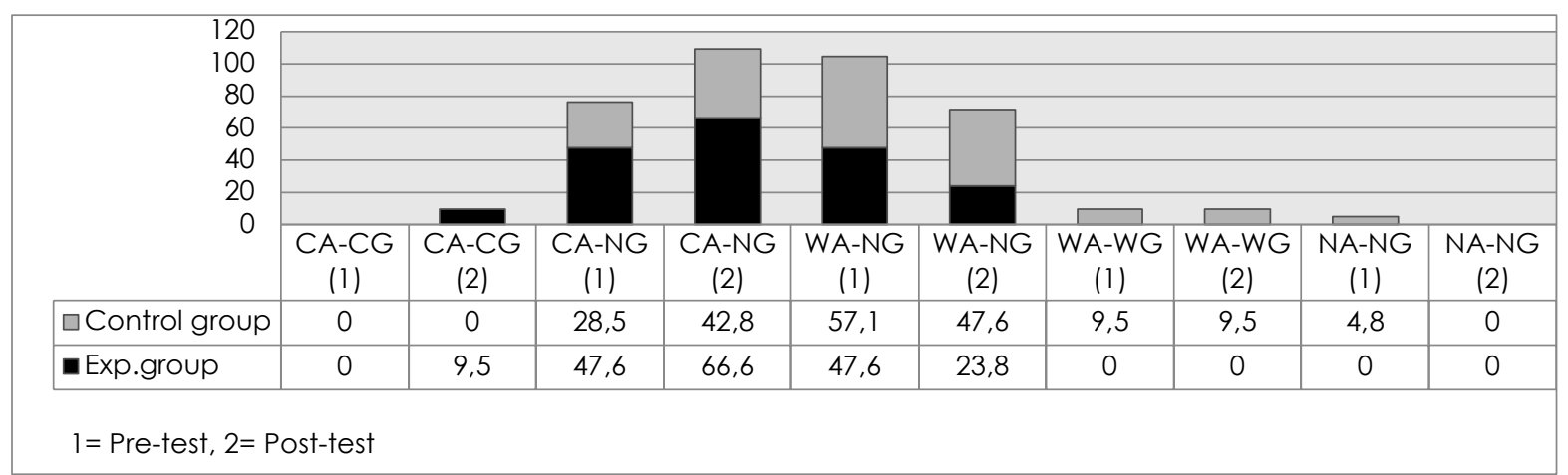

Figure 9. Analysis of Student Answers for Question-9 (f/\%)

- In the ninth question of HTAT at the "analyze" level, namely "You are warming up against the fire on a cold winter day. Which of the following statements about your warming is correct?", none of the students in both experimental and control groups could respond in the pre-test in CA-CG category. The feedback was received from 9.5\% of the experimental group of students in the post-test.

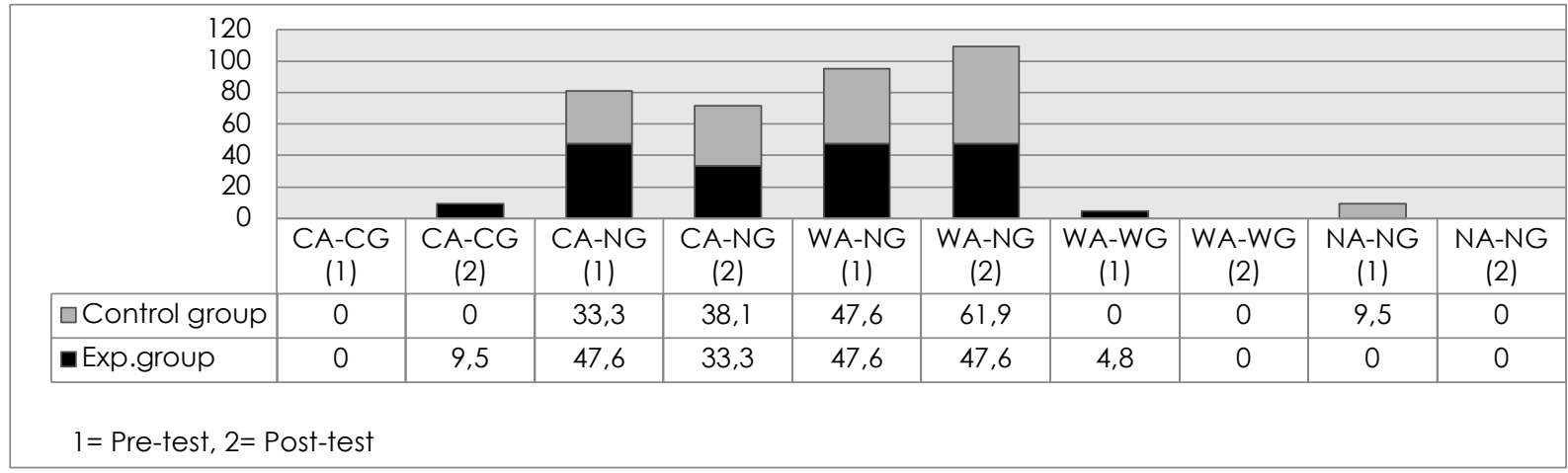

Figure 10. Analysis of Student Answers for Question-10 (f/\%)

- In the last question at the "remember" level, namely "Which of the following statements about the flow direction of the heat is correct?", the students of neither group could respond this question in the CA-CG category in the pre-test. Meanwhile, $9.5 \%$ of the experimental group of students responded in the CA-CG category in the post-test.

\section{DISCUSSION}

Within the scope of the study, which examined the students' misconceptions regarding the topic of heat and temperature in the fifth-grade science course, the effect of the $5 \mathrm{E}$ learning 
model, which was enriched with guidance materials providing conceptual change, on conceptual understanding was also investigated. It is seen that all these results obtained in the context of the study are compatible with the results of the studies examining the effect of teaching supported by the conceptual change model (Gürbüz, 2008; Demir, 2010; Ertaş, 2013; Kılıçoğlu, 2011). It is stated that students can reveal their thoughts more easily when in-class language is used effectively in the classroom in teaching supported by conceptual change (Hennessey, 1993). It is stated that applying learning models together for conceptual change will provide many benefits, such as more frequent use of self-monitoring skills by students (Beeth, 1998). Concerning the conceptual change texts, when the studies in the relevant literature are examined, when evaluated in terms of replacing alternative concepts with scientific ones, it seems that there are results that support the research (Bayır, 2000; Çakır, Uzuntiryaki \& Geban, 2002; Diakidoy, Kendeou \& loannides, 2003; Uzuntiryaki \& Geban, 1998; Ünlü, 2000).

In the literature studies on heat and temperature, there are many national and international studies from past to present (Acemioğlu \& Doğan, 2019; Bar \& Travis, 1991; Durmuş, 2014; Erickson, 1979, 1980; Gökulu, 2015; Harrison, Grayson \& Treagust, 1999; Jara -Guerro, 1993; Kesidou \& Duit, 1993; Liu, Lin \& Kinshuk, 2010; Sarı Ay, 2011; Sarıaya, 2019; Solak, 2016; Tamkavas, 2019; Türkoğuz \& Yankayış, 2015; Uzoğlu \& Aktürk, 2019; Ültay \& Can, 2015). Within the scope of the study, in addition to the students' concepts about heat and temperature that are in accordance with scientific facts, concepts that are not suitable for scientific facts were determined and these misconceptions are summarized in Table 4.

Table 4. Misconceptions about "Heat and Temperature" Detected in Students

\section{Detected misconceptions}

Heat and temperature are the same concepts.

As the amount of substance increases, heat and temperature increase.

When two substances with different temperatures are mixed, their final temperature is equal to the sum of their initial temperatures.

The temperature is energy.

Temperature is also a concept that is given and received.

The units of heat and temperature are the same.

As shown in Table 4, the students' misconception about heat and temperature that "temperature is a concept that is given and taken like heat" draws attention. When the students' responses to the question of "where the concepts of heat and temperature are used in daily life" are examined, it is revealed that this error stems from the students' discourse in daily life. Therefore, some of the students had misconceptions that the more the substances, the more the temperature and heat increased. In other words, the reason for these misconceptions 
Yılmaz Vahit Işcan \& Hatice Güngör Seyhan, The Effect of the 5E Learning Model Supported...

in students is that when they use the concept of heat, they still think this concept is the same as temperature. When the students responded to the question, namely "Is the heat of an iceberg large enough to sink the titanic bigger, or the heat of a burning match piece?"m the misconceptions were determined that the higher the amount of substance, the higher the temperature. The misconception that "heat and temperature are the same concepts" is a common misconception in the literature. This error was also observed in the students included in our study group before the implications. However, based on the findings, this misconception arose from the discourses in daily life. Therefore, it can be eliminated in students with the "understand" and higher-level activities of Bloom's Revised Taxonomy.

\section{CONCLUSION}

With the $5 E$ learning model supported by a conceptual change model and enriched with relevant guidance materials, students' discontentment, comprehensibility, rationality and usefulness, the study was aimed at increasing the students' awareness of their misconceptions. In this study, the worksheets were aimed at activating the students' self-monitoring skills by presenting the problem situations that reflect the daily life in order to create cognitive conflicts in the students. Afterwards, the targeted implications for the experimental group were completed by performing an activity or designing an activity and then presenting the conceptual change texts in order for the students to offer solutions to these problem situations. The results showed that after the implications, the students' success about the topic of heat and temperature in the experimental and control groups was higher, compared to their success before the implications. However, after the analysis of HTAT post-tests, this increase was in favor of the experimental group. With the 5E learning model enriched with conceptual change texts and related guidance materials used in this study, students became more aware of their misconceptions. In this process, a conflict and discontentment between the new concepts and existing students' misconceptions were ensured. Since the students in the control group could not experience this discontent, they did not realize that they had misconceptions, thus they could not establish a relationship with the new concept, and learning did not take place, or this situation resulted in the formation of new misconceptions. Students' skills, e.g., asking questions, controlling themselves and their peers, and designing experiments were mobilized by supporting the constructivist approach with conceptual change and the combined use of many techniques. It also allowed students to use their self-monitoring skills frequently.

\section{SUGGESTIONS}

It is not known how effective teaching using many techniques and methods such as analogy, worksheet, conceptual change text, or computer-assisted teachings, which provide conceptual change using the $5 E$ learning model, will be. There are still gaps in the literature 
regarding the differences in how to use these methods. In particular, developing activities in which all materials suitable for the 5E learning model are used together can also be used to improve student understanding in other science topics. While preparing conceptual change studies, the contents of the materials or activities should be developed based on the teachers' opinions in order to examine the reasons for the misconceptions seen in students in more detail. As stated in many studies examining misconceptions, full/semi-structured interviews should be conducted with students by random or purposeful sampling method after the implications in order to reveal the reasons of misconceptions in students.

\section{REFERENCES}

Acemioğlu, R., \& Doğan, Y. (2019). Investigating pre-service science teachers' misconceptions on heat and temperature. Journal of Muallim Rifat Faculty of Education, 1 (1), 54-67.

Akgün, Ö. E., \& Deryakulu, D. (2007). The effects of refutational text and predict-observeexplain strategies on students' levels of cognitive conflict and conceptual change. Ankara University Journal of Faculty of Educational Sciences (JFES), 40(1), 17-40. DOI: doi.org/10.1501/Egifak_0000000148

Anderson, B., (1990). "Pupils' conceptions of matter and its transformations", Studies in Science Education, 18, 53-85.

Atasoy, \$̧. (2008). Researching effectiveness of worksheets developed to remedying student teachers' misconceptions about Newton's laws of motion. Unpublished PhD Thesis, Karadeniz Technical University, Institute of Science, Trabzon.

Ayas, A., \& Özmen, H. (2002). A study of students' level of understanding of the particulate nature of matter at secondary school level. Boğaziçi University Education Journal, 19(2), 45-60.

Aykutlu, I., \& Şen, A. İ. (2011). Using analogies in determining and overcoming high school students' misconceptions about electric current. Necatibey Faculty of Education Electronic Journal of Science and Mathematics Education, 5(2), 221-250

Bar, V., \& Travis, S. A. (1991). Children's views concerning phase changes. Journal of Research in Science Teaching, 28, 363-382.

Başer, M., \& Çataloğlu, E. (2005). Effect of conceptual change oriented instruction on remediation of students' misconceptions related to heat and temperature concepts. Hacettepe University Journal of Education, 29, 43-52. 
Yılmaz Vahit Işcan \& Hatice Güngör Seyhan, The Effect of the 5E Learning Model Supported...

Başer, M., \& Geban, Ö. (2007). Effectiveness of conceptual change instruction on understanding of heat and temperature concepts. Research in Science \& Technological Education, 25(1), 115-133.

Bayır, G. (2000). Effect of conceptual change text instruction on students' understanding of chemical change and conservation of mass concepts. Unpublished Master Thesis, METU, Institute of Science, Ankara.

Beeth, M. E. (1998). Facilitating conceptual change learning: The need for the teachers to support metacognition. Journal of Science Teacher Education, 9(1), 49-61.

Bilgin, İ., \& Geban, Ö. (2001). Eliminating the misconceptions of high school 2nd grade students about chemical balance by using the analogy method. Beginning of the New Millennium Science Education Symposium in Turkey, (7-8 September), Istanbul, Maltepe University, Print book: Conference publication: Turkish.

Board of Education. (2013). Secondary school science lesson (5th, 6th, 7th and 8th grades) curriculum. Ankara: MoNE.

Can Şen, H. \& Eryılmaz, A. (2011). An achievement test development study: reliability and validity investigation of simple electric circuits' achievement test. Yüzüncü Yıl University Journal of Education, 8(1), 1-39.

Çakır, Ö. S., Uzuntiryaki, E., \& Geban, Ö. (2002). Contribution of conceptual change texts and concept mapping to students' understanding of acids and bases. Paper Presented at The Annual Meeting of The National Association For Research in Science Teaching, New Orleans, LA.

Çalık, M., Ünal, S., Coştu, B., \& Karataş, Ö. F., (2008). Trends in Turkish science education. Essay in Education, Special Edition, 23-45.

Çaycı, B. (2007). Examining of the effectiveness of conceptual changing approach on concept learning. Unpublished PhD Thesis, Gazi University, Institute of Educational Sciences, Ankara.

Çıldır, I., \& Şen, A. (2006). Identification of high school students' misconception about electric current by concept maps. Hacettepe University Journal of Education, 30(30), 92-101.

Clement, J., Brown, D., \& Zietsman, A. (1989). Not all preconceptions are misconceptions: Finding anchoring conceptions for grounding instruction on students' intuitions. International Journal of Science Education, 11, 554-565. 
Coştu, B., Çepni, S., \& Yeşilyurt, M. (2002). Use of computer-aided materials for misconceptions about process changes. V. National Science and Mathematics Education Congress, METU, Ankara.

Demir, M. (2010). The effect of conceptual change texts enriched with Meta conceptual processes on pre-service science teachers' conceptual understanding about force and motion. Unpublished Master Thesis. Gazi University, Institute of Educational Sciences, Ankara.

Demirel, Ö. (1999). The art of teaching from planning to evaluation, Pagem A Publications, ANKARA.

Diakidoy, I. A. N., Kendeou, P., \& loannides, C. (2003). Reading about energy: The effects of text structure in science learning and conceptual change. Educational Psychology, 28(3), 335-356.

Dole, J. A. (2000). Readers, texts and conceptual change learning, reading and writing. Quarterly, 16, 99-118.

Driver, R., \& Oldham, V. (1986). A constructivist approach to curriculum development. Studies in Science Education, 13, 105-122.

Driver, R. (1981). Pupils' alternative frameworks in science. European Journal of Science Education, 3, 93-101.

Driver, R., Asoko, H., Leach, J., Mortimer, E., \& Scott, P. (1994). Constructing scientific knowledge in the classroom. Educational Researcher, 23(7), 5-12.

Duit, R., \& Treagust, D. (1998). Learning in science: From Behaviorism towards social constructivism and beyond. (Ed: Fraser, B., and Tobin, K.). International Handbook of Science Education, 3-26, Kluwer Academic, UK: Dordrecht.

Durmuş, A. (2014). Effect of laboratory activities based on Predict-Observe-Explain (POE)' method on pre-service science teachers' understanding of 'Heat and Temperature' subject. Unpublished Master Thesis, Karadeniz Technical University, Trabzon.

Erdoğan, A., \& Özsevgeç, L. C. (2012). The effects of concept cartoons on eliminating students' misconceptions: Greenhouse effect and global warming. Turkish Journal of Education, I (2), 38-50. DOI: 10.19128/turje.181046

Erickson, G. L. (1979). Children's conceptions of heat and temperature. Science Education, 63(2), 221-230. 
Yılmaz Vahit Işcan \& Hatice Güngör Seyhan, The Effect of the 5E Learning Model Supported...

Erickson, G. L. (1980). Children viewpoints of heat: A second look. Science Education, 64(3), 323-336.

Ertaş, S. (2013). Electric current on 10th grade students effects of conceptual change removing misconceptions texts. Unpublished Master Thesis. Gazi University, Institute of Educational Sciences, Ankara.

Eryllmaz, A. (2002). Effects of conceptual assignments and conceptual change discussions on students' misconceptions and achievement regarding force and motion. Journal of Research in Science Teaching, 39(10), 1001-1015.

Gilbert, J. K., Osborne, R., \& Fensham, P. J. (1982). Children's science and its consequences for teaching. Science Education, 66(4), 623-633.

Gökulu, A. (2015). A study of prospective primary teachers' level of understanding of the "heat, temperature, change of state" concepts. Mersin University Journal of the Faculty of Education, 11 (2), 300-314. DOI: 10.17860/efd.56083

Gunstone, R. F. (1990). Children's science: A decade of developments in constructivist views of science teaching and learning. The Australian Science Teachers Journal, 36(4), 9-19.

Seyhan, H. G., \& Morgil, I. (2007). The effect of 5E learning model on teaching of acid-base topic in chemistry education. Journal of Science Education, 8(2), 120-123.

Gürbüz, F. (2008). An investigation on the effect of conceptual change text approach on removal of 6th grade students' misconceptions about heat and temperature. Unpublished Master Thesis, Atatürk University, Institute of Science, Erzurum.

Hanuscin, D. L., \& Lee, M. H. (2007). Using a learning cycle approach to teaching the learning cycle to pre-service elementary teachers. Paper presented at the 2007 annual meeting of the Association for Science Teacher Education, Clearwater, FL.

Harrison, A. G., Grayson, D. J., \& Treagust, D. F. (1999). Investigating a grade 11 student's evolving conceptions of heat and temperature. Journal of Research in Science Teaching, 36(1), 55-87.

Helm, H. (1980). Misconceptions in physics amongst South African students. Physics Education, $15,92-105$.

Hennessey, M. G., (1993). Students' ideas about their conceptualization: Their elicitation through instruction. Paper presented at the annual meeting of the National Association for Research in Science Teaching, Atlanta, GA. 
Hewson, P. W., \& Hewson, M. G. (1984). The role conceptual conflict in conceptual change and the design of science instruction. Instructional Science, 13, 1-13.

Howitt, D., \& Cramer, D. (2011). Introduction to SPSS statistics in psychology: For version 19 and earlier. Pearson.

Jaakkola, T., \& Nurmi, S. (2008). Fostering elementary school students' understanding of simple electricity by combining simulation and laboratory activities. Journal of Computer Assisted Learning, 24, 271-283.

Jara-Guerrero, S. (1993). Misconceptions on heat and temperature. In the proceedings of the Third International Seminar on Misconceptions and Educational Strategies in Science and Mathematics, Misconceptions Trust: Ithaca, NY.

Kaplan, F., \& Arslan, B. (2002). Comparison of question-answer technique and analogy technique in science education. V. National Science and Mathematics Education Congress, Ankara.

Kesidou, S., \& Duit, R. (1993). Student's conceptions of the second law of thermodynamics-an interpretative study. Journal of Research in Science Teaching, 30, 85-106.

Kllıçoğlu, G. (2011). The impact of conceptual change texts on misconceptions in social studies courses. Unpublished PhD Thesis, Gazi University, Institute of Educational Sciences, Ankara.

Köse, S., Ayas, A., \& Uşak, M. (2006). The effect of conceptual change texts instructions on overcoming prospective science teachers' misconceptions of photosynthesis and respiration in plants. International Journal of Environmental and Science Education, 1 (1), 78-103.

Köseoğlu, F., \& Kavak, N., (2001). Constructivist approach in science teaching. Gazi University Journal of Faculty of Gazi Education, 21 (1), 139-148.

Kul, S. (2014). Convenient statistical test selection guide. Plevra Bulletin, 8(2), 26-29.

Kurnaz, M. A., \& Çalık, M. (2008). Using different conceptual change methods embedded within 5E model: A sample teaching for heat and temperature. Journal of Physics Teacher Education Online, 5(1), 3-10.

Lanier, J., \& Little, J. W., (1986). Research on teacher education. In M. Witttrock (Ed.) Handbook of research on teaching. New York: Macmillan. 
Yılmaz Vahit Işcan \& Hatice Güngör Seyhan, The Effect of the 5E Learning Model Supported...

Lawshe, C. H. (1975). A quantitative approach to content validity. Personnel Psychology, 28, $563-575$.

Liu, T.C., Lin Y. C., \& Kinshuk. (2010). The application of Simulation-Assisted Learning Statistics (SALS) for correcting misconceptions and improving understanding of correlation. Journal of Computer Assisted Learning, 26(2), 143-158. DOI: 10.1111/j.1365$2729.2009 .00330 . x$

McKillup, S. (2011). Statistics explained: An introductory guide for life scientists. Cambridge University Press.

Mestre, J. P., (1994). Cognitive aspects of learning and teaching science. In S. J. Fitzsimmons \& L. C. Kerplelman (Eds.) Teacher enhancement for elementary and secondary science and mathematics: Status, Issues, and Problems. Washington D.C.: National Science Foundation.

Mikkila-Erdmann, M. (2001). Improving conceptual change concerning photosynthesis through text design. Learning and Instruction, 11 (3), 241-257. DOI: 10.1016/S0959-4752(00)00041-4

Novak, J. D. (1977). A theory of education. Cornell University Press, Ithaca, NY.

Okur, M. (2009). A comparison of different conceptual change methods: A sample for sound propagation topic. Unpublished Master Thesis, Karadeniz Technical University, Institute of Science, Trabzon.

Osborne, R. J. (1985). Building on children's intuitive ideas, In R. J. Osborne, \& P. Freyberg, (Eds) Learning in science. The implications of children's science. Auckland, Heinemann.

Osborne, R. J., \& Wittrock, M. C. (1983). Learning science: A generative process. Science Education, 67 (4), 489-508.

Özmen, H., \& Yıldırım N. (2005). The effect of worksheets on student achievement: Acids and bases example, Journal of Turkish Science Education, 2(2), 124-140.

Palmer, D. H. (2001). Students' alternative conceptions and scientifically acceptable conceptions about gravity. International Journal of Science Education, 23(7), 691-706. DOI: 10.1080/09500690010006527

Palmer, D. H. (2003). Investigating the relationship between refutational text and conceptual change, Science Education, 87(5), 663-684.

Posner, G. J., Strike, K. A., \& Hewson, P. W. (1982). Accommodation of a scientific conception: Toward of conceptual change, Science Education, 66(2), 211 -227. 
Richardson, V. (1997). Constructivist teaching and teacher education: Theory and practice. In V. Richardson (ed.), Constructivist teacher education: Building new understandings. Washington, DC: Falmer Press, 3-14.

Rogers, F., Huddle, P. A., \& White, M. D. (2000). Using a teaching model to correct known misconceptions in electrochemistry. Journal of Chemical Education, 77(1), 104-110.

Saka, A., \& Yllmaz, M. (2005). Material development and application based on worksheets in computer aided physics teaching, Turkish Online Journal of Educational Technology, $4(3), 120-131$.

Saka, A. (2006). The effect of $5 E$ model on removing science student teachers' misconceptions about genetics, Unpublished PhD Thesis, Karadeniz Technical University, Institute of Science, Trabzon.

Sander, M., (1993). Erroneous ideas about respiration: The teacher factor, Journal of Research in Science Teaching, 30, 919-934.

Sarı Ay, Ö. (2011). The effect of using conceptual change texts and students opinions in the misconceptions identified removal in the unit of states of matter and heat in the science and technology course of primary 8th class. Unpublished Master Thesis, Hacettepe University, Institute of Social Sciences, Ankara.

Sari Ay, Ö., \& Aydoğdu, C. (2015). The effect of conceptual change texts on overcoming misconceptions about states of matter and heat. Hacettepe University Journal of Education, 30(2), 99-111.

Sarıaya, S. (2019) Determine and eliminate the misconceptions about heat and temperature of secondary school students. Mersin University, Institute of Educational Sciences, Mersin.

Solak, E. (2016). Analysis middle school students' conceptual understanding on heat and temperature concepts and argumentation based activity proposal. Unpublished Master Thesis, Ballkesir University, Institute of Science, Balıkesir.

Stofflett, R. (1994). The accommodation of science pedagogical knowledge: the application of conceptual change constructs to teacher education, Journal of Research in Science Teaching, 31 (8), 787-810.

Storey, R. D. (1989). "Textbook errors and misconceptions in biology: Photosynthesis", American Biology Teacher, 51, 271-274.

Tabachnick, B. G., Fidell, L. S., \& Ullman, J. B. (2007). Using multivariate statistics (Vol.5). Boston, MA: Pearson. 
Yılmaz Vahit Işcan \& Hatice Güngör Seyhan, The Effect of the 5E Learning Model Supported...

Tamkavas, Ç. H. (2019) Perception of prospective science teacher about heat and temperature concepts: A phenomenographical research. Unpublished Master Thesis, Necmettin Erbakan University, Institute of Education Sciences, Konya.

Taşıdere, E. (2013). Effect of conceptual change oriented instruction on students' conceptual understanding and decreasing their misconceptions in DC electric circuits. Creative Education, 4(4), 273-282

Taşıdere, E., Korur, F., \& Eryılmaz, A. (2012). Different evaluation of misconceptions with threestep questions. X. National Science Congress, 27-30.

Thomaz, M. F., Malaquias, I. M., Valente, M. C., \& Antunes, M. J. (1995). An attempt to overcome alternative conceptions related to heat and temperature. Physics Education, 30, 19-26.

Toka, Y., \& Aşkar, P. (2002). The effect of cognitive conflict and conceptual change text on students' achievement related to first degree equations with one unknown. Hacettepe University, Journal of Education, 23, 211-217.

Treagust, D. F. (1988). Development and use of diagnostic tests to evaluate students' misconceptions in science. International Journal of Science Education, 10(2), 159-169.

Türk, F., \& Çalık, M. (2008). Using different conceptual change methods embedded within 5E model: A sample teaching of endothermic-exothermic reactions. Asia-Pacific Forum on Science Learning and Teaching, 9(1), Article 5.

Türkoğuz, S., \& Yankayış, K. (2015). Teacher' views related to the effects of misconceptions about heat and temperature on daily life. Bayburt Journal of Education, 10(2), 498-515.

Uşun, S. (2006). Distance learning. Nobel Publishing Distribution Ankara.

Uzoğlu, M., \& Aktürk, F. (2019). The use of letter writing activity to identify 5th grade students' misconceptions about heat and temperature. Kastamonu Education Journal, 27(5), 2043-2055.

Uzuntiryaki, E., \& Geban, Ö. (1998). The use of conceptual change texts and concept maps in the teaching of the primary education $8^{\text {th }}$ grade solution subject, III. National Science Education Symposium, Trabzon.

Ültay, E., \& Can, M. (2015). Determining the conceptual knowledge of pre-school teacher candidates about heat and temperature. Giresun University, Karadeniz Journal of Social Sciences, Special Issue, I, 179-203. 
Ünlü, S. (2000). The effect of conceptual change text in students' achievement of atom, molecule, matter concepts. Unpublished Master Thesis, METU, Institute of Science, Ankara.

Ürek, R. Ö., \& Tarhan, L. (2005). An active learning application based on constructivism to remedy misconceptions on "covalent bonding". Hacettepe University Journal of Education, 28, 168-177.

Veneziano L., \& Hooper J. (1997). A method for quantifying content validity of health-related questionnaires. American Journal of Health Behavior, 21 (1), 67-70.

Webb, N. L. (1997). Determining alignment of expectations and assessments in mathematics and science education. NISE Brief, 1(2). Madison, WI: University of Wisconsin-Madison, National Institute for Science Education.

White, R. T., \& Gunstone, R. F. (1989). Meta learning and conceptual change. International Journal of Science Education, 11 (5), 577-586.

Wilcox, R. (2011). Modern statistics for the social and behavioral sciences: A practical introduction. CRC press.

Yager, R. E. (1991). The constructivist learning model: Towards real reform in science education. The Science Teacher, 58(6), 52-57.

Yurdugül, H. (2005). Using content validity indexes for content validity in scale development studies. XIV. National Educational Sciences Congress, Pamukkale University Faculty of Education, Denizli. 
Yılmaz Vahit Işcan \& Hatice Güngör Seyhan, The Effect of the 5E Learning Model Supported...

\section{APPENDIX \\ TEACHER MATERIAL-I \\ EXPERIMENTAL GROUP}

\begin{tabular}{|c|c|}
\hline & LESSON PLAN \\
\hline PART I & \\
\hline Lesson name & Science \\
\hline Class & $5^{\text {th }}$ grade \\
\hline Subject & Heat and temperature \\
\hline Duration & 4 lesson hours \\
\hline
\end{tabular}

\section{PART II}

\begin{tabular}{|c|c|}
\hline Student acquisitions & Explains the basic differences between heat and temperature. \\
\hline Unit concepts & Heat and temperature \\
\hline $\begin{array}{l}\text { Teaching-learning } \\
\text { methods and } \\
\text { techniques }\end{array}$ & $\begin{array}{l}\text { Teaching by presentation strategy, teaching by discovery strategy, } \\
\text { question and answer technique, experimental method, conceptual } \\
\text { change text }\end{array}$ \\
\hline $\begin{array}{l}\text { Educational } \\
\text { technologies used }\end{array}$ & Smart board \\
\hline $\begin{array}{l}\text { Introduction, } \\
\text { attention grabbing }\end{array}$ & $\begin{array}{l}\text { The narrative activity named "In my opinion" is distributed to the } \\
\text { students. Brainstorming activities are done first by using the question- } \\
\text { answer technique. Afterwards, students are asked to write their } \\
\text { feedback in the relevant places on the worksheet. The conceptual } \\
\text { change text (In my opinion) is distributed to the students, } \\
\text { explainingwhy possible misconceptions would not be appropriate. }\end{array}$ \\
\hline Exploration & $\begin{array}{l}\text { Students are asked to read the text in the activity "Which is hot and } \\
\text { which is cold" on the worksheet. In order to provide feedback to the } \\
\text { problem statement directed at the end of the text, they are first asked } \\
\text { to respond verbally by using the brainstorming technique, and then in } \\
\text { writing to the relevant place. } \\
\text { In order to enable the students to reach the correct answer of the } \\
\text { problem sentence given at the end of the text "Which is hot and which } \\
\text { is cold", the students in the experimental student group were divided } \\
\text { into groups of three and they were asked to do the experimental } \\
\text { activity called "You make the decision" on the worksheet. Questions } \\
\text { about the experiments carried out after the experimental activity were } \\
\text { posed and they were asked to write their answers and justifications in } \\
\text { the relevant places on the worksheet. Afterwards, thermometers are } \\
\text { distributed to the student groups and they are asked to finish the } \\
\text { experimental study called "You make the decision". At the end of the } \\
\text { experimental activity, the conceptual change text (Which is hot and } \\
\text { which is cold) is distributed to the students, explaining why possible } \\
\text { misconceptions in the answers to the question posed would not be } \\
\text { appropriate. }\end{array}$ \\
\hline
\end{tabular}




\begin{tabular}{|l|l|}
\hline Explanation & $\begin{array}{l}\text { We use the concepts of "heat and temperature" in many places in our } \\
\text { daily life. Although the concepts of heat and temperature are related to } \\
\text { each other, they do not mean the same thing. The type of energy that is } \\
\text { transferred due to the temperature difference between substances, in } \\
\text { other words, that can be exchanged between substances is called heat. } \\
\text { Temperature, on the other hand, is a value that shows how hot or cold a } \\
\text { substance is relative to another substance. } \\
\text { The details of the explanations based on the short description above are } \\
\text { given during the lesson. }\end{array}$ \\
\hline PART III & $\begin{array}{l}\text { Worksheets for the "Energy bomb" activity are distributed to the students. } \\
\text { In this activity, it is expected that the questions asked to the students are } \\
\text { given verbally before the activities and then in writing to the relevant } \\
\text { places on the worksheet. }\end{array}$ \\
\hline $\begin{array}{l}\text { Assessment and } \\
\text { Evaluation }\end{array}$ & $\begin{array}{l}\text { After the necessary explanations are given in the discussion environment } \\
\text { with the students, they are asked to review the answers and justifications } \\
\text { they gave at the end of the "Energy bomb" activity on the worksheet. If } \\
\text { there are any similarities and/or incompatibilities they encounter after the } \\
\text { reviews, they are asked to write them in the relevant place with their } \\
\text { justifications. Afterwards, they are asked to complete the fill-in-the-blank } \\
\text { questions that will provide a brief evaluation of the concepts, facts and } \\
\text { events targeted during this lesson. }\end{array}$ \\
\hline
\end{tabular}




\section{STUDENT MATERIAL-I}

EXPERIMENTAL GROUP

\section{"IN MY OPINION" ACTIVITY}

Hasan, who is drinking tea at home on a winter day, realizes that he is cold. He wonders (the temperature/heat) of the room and looks at the thermometer. It realizes that the room (temperature /heat) is $19^{\circ} \mathrm{C}$ and increases the boiler's setting. Afterwards, he observes that the wet clothes on the heater are dry as they receive it from the heater (temperature/heat). (The concepts of temperature/heat are given in parentheses. Circle which of these concepts you think will be correctly placed in the sentences in the text you read. If you think both concepts will be placed correctly, you can mark both concepts. Write briefly why you chose the concepts you have circled with your reason).


Considering your answers and justifications for the "In My Opinion" activity, answer the following questions.

4. Where do you often use the concept of temperature in daily life? Write it as an example sentence?

5. Where do you often use the concept of heat in daily


After your answers to the above question and your justifications, please ask your teacher for the conceptual change text titled "In My Opinion". 


\section{"IN MY OPINION"}

For some students, it is quite normal for the heat to be lower than yesterday, or for a baby or child to have a sudden rise in body heat in the simplest upper respiratory tract infection. In fact, according to some students,
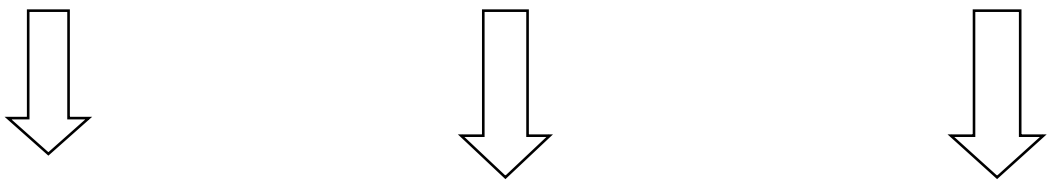

.....What wet laundry takes from the sun to dry is not "temperature" but "heat".

Well, aren't HEAT and TEMPERATURE the same thing

?

Now let's ask you to stay still for a few seconds. Although you seem .....
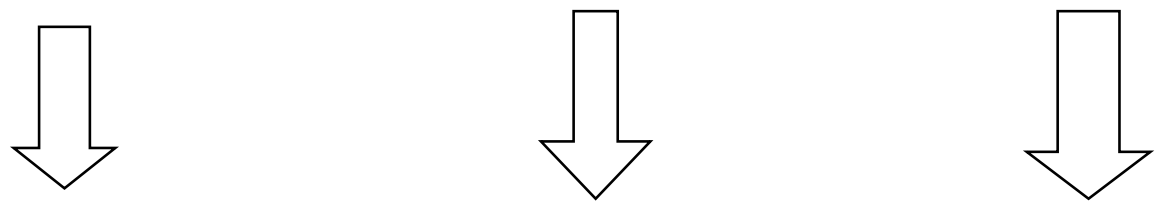

So what does it mean to have more or less energy in an atom/molecule?

How much vibrating energy something has is related to the HEAT/TEMPERATURE of that thing.

HEAT

几

The TOTAL energy of
TEMPARATURE

I

the MEASURE of their average energy of

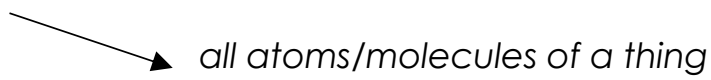


It is HEAT that will increase or decrease the TEMPERATURE of something. If heat is added, the temperature

To measure how much energy something has, let's write some imaginary numbers for each molecule below:

HEAT is TOTAL energy.
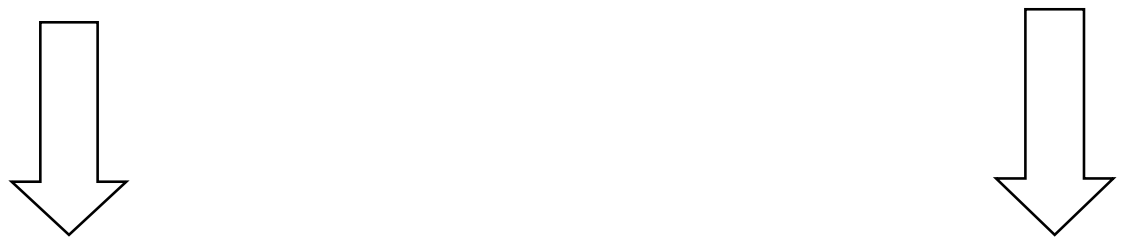


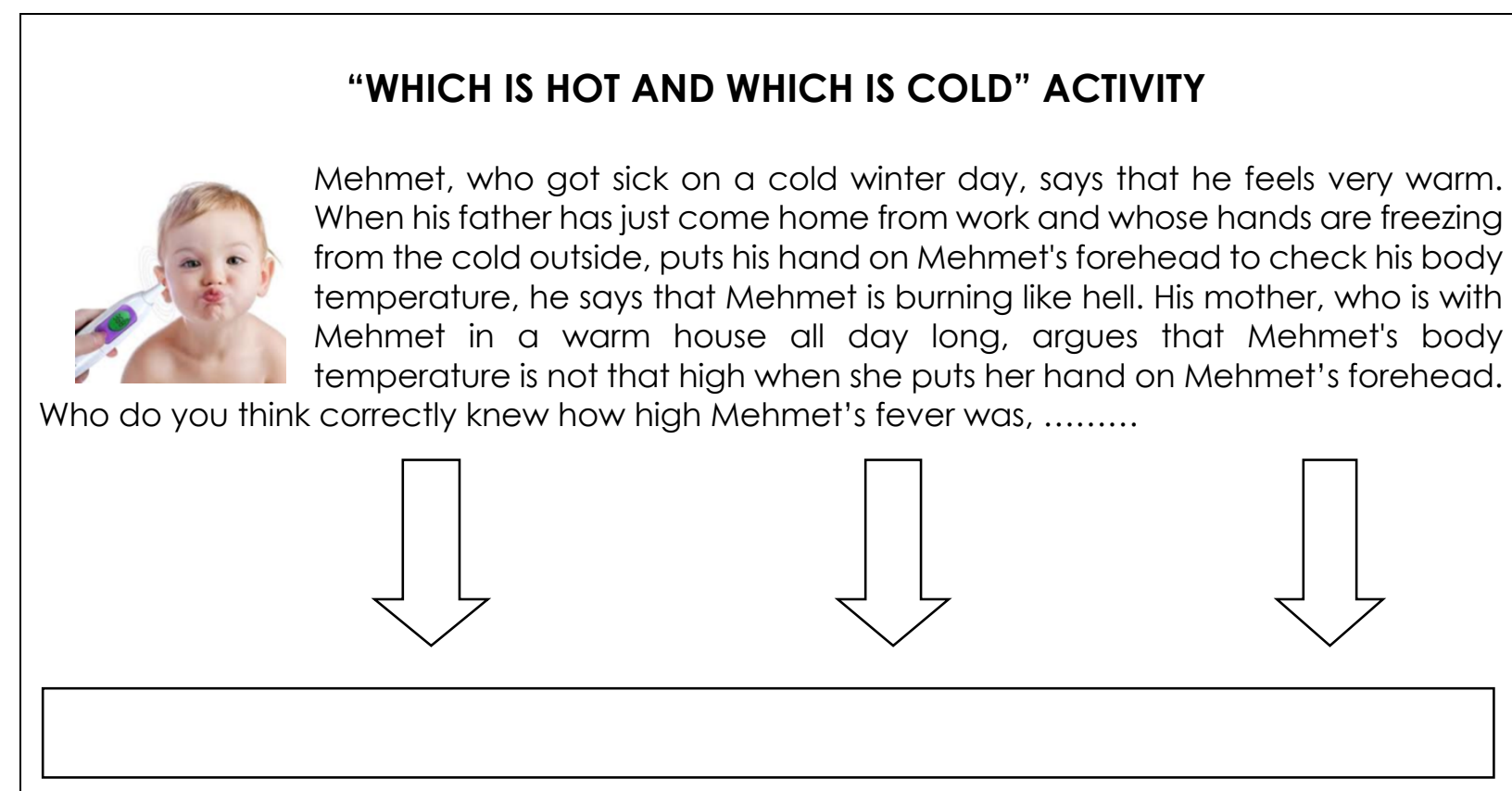

After your answers and justifications to the above problem statements, do the following activities.

\section{You make the decision}

Place the beakers labeled A, B, C that filled with water on the table in alphabetical order. Soak your left hand in the beaker labeled $A$ and your right hand into the beaker labeled C. After a few seconds, remove both hands from the beakers at the same time and simultaneously soak both hands in the beaker labeled $B$.

Do you think the water in the beaker labeled B is hot or cold? Write your answer with your justification below.

-With the help of the thermometers given to you, first measure the temperature of the water in the beaker labeled " $\mathrm{C}$ " and record the value you have measured:

- With the help of the thermometers ...
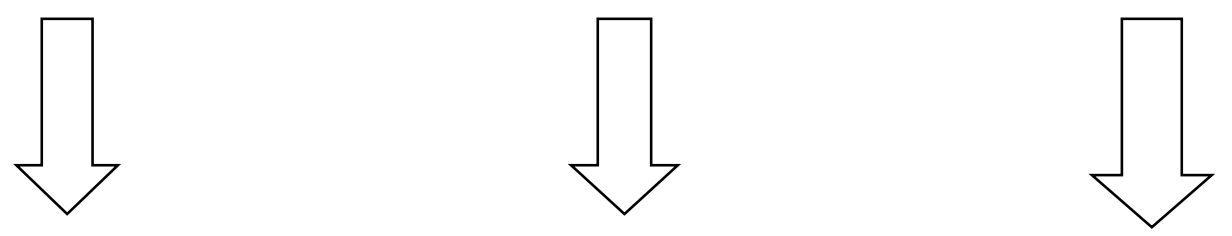

After your answers to the above question and your justifications, please ask your teacher for the conceptual change text "Which is hot and which is cold". 


\section{WHICH IS HOT AND WHICH IS COLD?}

Since our body has a temperature, measuring temperature by direct contact will not give accurate results. In the activity "Which is hot and which is cold", some students expressed the water in (B) beaker as "HOT" when they evaluated it according to one hand, but as "COLD" when they evaluated
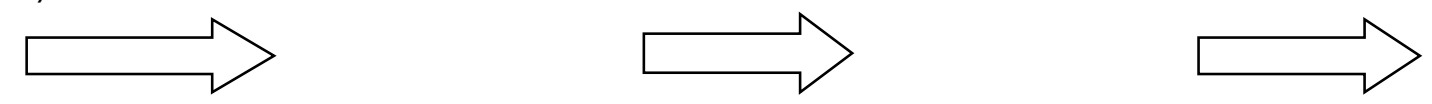

very sweet or very salty meals.

When you first soak your hand in water that is warmer than.
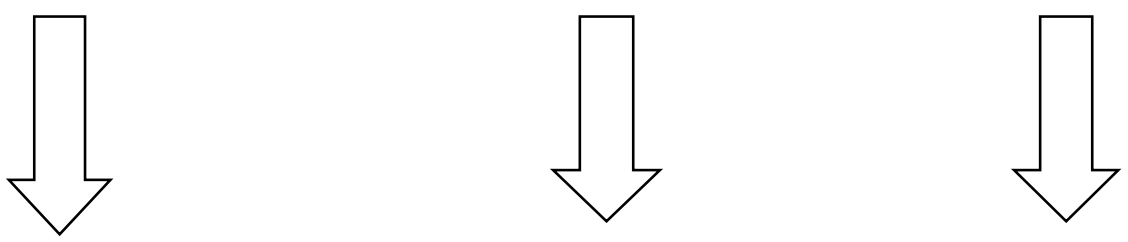

When we soak our hand, which has reached a much lower temperature than our body temperature, in water that has been waiting at room temperature, we feel as if the water is "hot" because the energy (heat) flow will be towards our hand. In fact, the temperature value of the water we describe as "cold" or "hot" in both cases is the same: $24^{\circ} \mathrm{C}$. Therefore, temperature is a measurable concept and also requires a........


\section{HEAT moves from hot objects to cold objects.}

Because an ice cube is colder than your finger, the heat from your finger will move towards the ice. Ice does not make your finger....
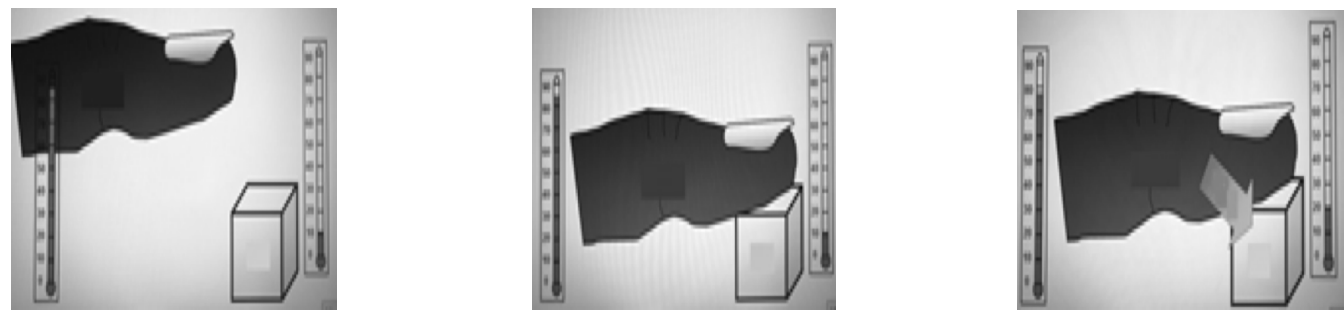

\section{“ENERGY BOMB” ACTIVITY}
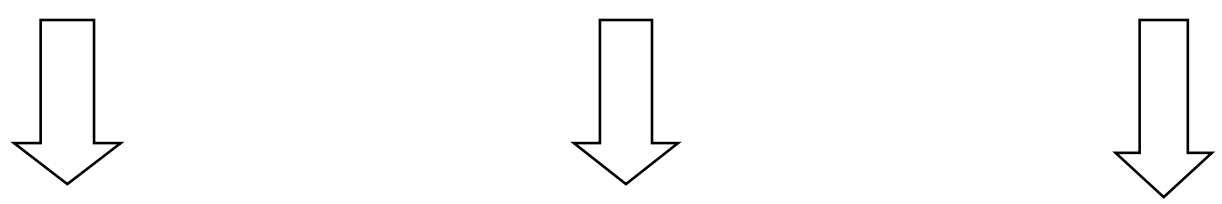